\title{
Money Supply and Prices Relation in Albanian Economy
}

\author{
Güngör Turan \\ Phd in Economics, Department of Economics, Epoka University, Tirana; gturan@epoka.edu.al \\ Jona Hoxhaj \\ MSc student in Economics, Epoka University, Tirana; jhoxhaj@epoka.edu.al
}

\section{Doi:10.5901/ajis.2015.v4n3s1p577}

\begin{abstract}
Paper aims to examine the relationship between money, represented by M1, and prices, represented by Consumer Price Index (CPI) in Albania. Monthly data are used from 2000:M1 to 2015:M1. Particularly, paper represents the relation of these variables in different economies similar to Albanian economy. The main part includes an econometric model, implementation of Johansen Co-integration Test which will correctly disclose the relationship of M1 and Inflation. In the last part of the paper, as it was forecasted the empirical results reveal positive relation between the variables, indicating that increase in money supply would consequently lead to an increase in inflation.
\end{abstract}

Keywords: inflation, money supply, Albania, co-integration test.

\section{Introduction}

Albania as a post communist country has passed difficulties in development and progress of economy and social aspects of life, the year after the regime collapsed was followed with economic downturn, social problems and emigration. Even though it has not passed through pre transition period, after 1991 the progress was substantial, the stabilization program supported by International Monetary Fund (IMF) proved to be very efficient. In 1997 the development was jeopardized by a period of turmoil passing through a very challenging situation, recovering from pyramidal schemes, social and political problems of civil hooliganism made that year the hardest obstacle of the transition period. From 1998 to present Albania has experienced positive growth rate and low inflation rates. Services, constriction and agriculture sectors are the main sources of GDP per capita of population(INSTAT, 2015). According to the Law "On the Bank of Albania", the primary objective of the Bank of Albania is to achieve and maintain price stability(BoA). This implies to target low but positive inflation; quantitative expression is $3.0 \%$ with tolerance of $+/-1 \%$. By targeting inflation Bank of Albania tries to achieve economic growth and safeguard financial stability.

Albania after communism has repaired the economic and social aspects of development, many of macroeconomic indicators have been stable and have achieved the forecasted values, but still it remains to be a developing country under progress. As argued by Bolle and Meyers (2006) national currency is also one of these indicators, which has been mainly stable but still high level of dollarization means that it has not achieved the BoA's objective to have financial and economic stability.

M1 is broadly accepted as narrow definition of money supply, considering mainly currency and checkable deposits, the money nation's use for day-to-day economic transactions. The behavior of M1 is monitored by Central Banks of States. In Albania responsible for controlling and monitoring of money supply is Bank of Albania (BoA). CPI on the other side is an index that produces monthly data on changes in the prices paid by consumers for respective basket of goods and services. These two variables will be used in order to find out the co-integration of money supply with inflation in Albania.

This paper will be consisting three major divisions; the first part of the paper maintains the literature review, which will give a broader picture for the variables used in this model and for the relation of the money supply and inflation in other Balkan countries and other developing countries across the world, having similar economy as Albania. The second part of the paper, which is the main part, will be elaborated by performing econometric modeling and testing in Eviews8. Tests which will be performed are Unit Root testing for stationary and non stationary data, Johansson Co integration test and Granger causality test. These will give concrete empirical results related to relation of the money supply and inflation in Albania. The last part of the paper will conclude and review the results founded by the tests performed, in order to sum up the relation of $\mathrm{M} 1$ and $\mathrm{CPI}$ in Albanian economy, based on monthly data for 14 years. 


\section{Literature Review}

In a very broad range of studies done related to relation of money supply and inflation, majority of them are considering it as very important issue and highly reliable in determining the financial and macroeconomic stability of countries. Based on the literature and Central Banks expectations and results, in majority of developing and developed countries this relation is positive, but high dependence of Albania's monetary policy on European Union policies can cause the relation to deviate from expectations, as country is trying to adopt the policies of the Union.

A very significant study was conducted by Simic \& Malesevic-Perovic (2012) related to 6 Balkan countyes; Bulgaria, Coratia, Macedonia, Romania, Slovenia and Turkey. The main objective of the study was finding out the reation of output and prices to a shock in monetary policy, finding out that monetary policy is inefficinet in effecting output and prices as this countries are limited in monetary policy usage. In more detailed in Bulgeria prices and monetary policy show positive relation but the study consideres this finding not to be very effective as Bulgeria is a small country in Euro area and has strong links on economic indicators of Europe. Croatia shows to have negative results in firs few months and than the postive effect of the monetary policy shocks is seen on prices, considering Croatian case as having some effect on prices. Croatia has exhchange rate targeting which gives them few freedom in conducting monetary policy. In Macedonia the effect of monetary policy shock on prices is negative even with 8 lags and to conclude the authors sugest that monetary policy may effect prices for a while. In Romania there is no effect of monetary policy shocks on prices, another country that is part of the sample is Solvenia which has positive effect of monetary policy on prices but it is not able to effect the prices and the main reason given from the author is the prepartion for the euro area membership and alignment with ECB monetary policy. As the five countries discussed above have not been able to have effect on prices even though some have positive effect of monetary policy with prices they are statistically insiginificant, contrary to them Turkey has positive effect of monetary policy on prices and the relation is statistically siginificant. The main reasons explained by the authors as support to the results are; Turkey is larger economy comparing to 5 other countries of the sample and the link of Turkey with EU is weaker. These findings are in contrast to the evidences for developted countries, but as the sample countries are not having very stable monetary policy and macroeconomic indicators bacause of being still not developing process. Their indicators are highly effected by ECB policies and laws.

A very similar study to this paper was done for Suriname from Gaurisankar at al. (2011) finding out the relation of money and prices using annual data for M1 and CP1 for period 1980-2010. The tests used were bivariate dynamic vector autoregression model which enabled the usage of Granger Causality analysis to examine the long run and short run relationship. Results show that the long run relationship is run from prices to money and not from money to prices. This contrast finding related to other economies has been attributed from the others to occurrence of several episodes of currency depreciation and wage price incidents during 1980s and 1990s. In short run the relation of money and prices is positive.

Paun and Topan (2013) in their study for inflation and money relation for Romanian economy conclude that; inflation is the main monetary phenomenon with structural monetary causes, but consider M2 is more statistically effecting inflation and there are no statisitical relevance that M1 effects inflation. In Romanian economy credit expantion has high relevance in inflation as it is part of M2. Authors suggest that more sophisticated tools should be employed in order to convey simple ideas that were common knowledge among respectable economists, including here the fact that inflation has effect on fiat money contemporary setting, with increases in money supply managed by central banks.

Madurapperuma (2007) considers that the discussion of the relation between money, inflation and growth should be revisit. The evidences of this working paper confirm a strong postive relationship between money and prices, money causes inflation. The study indicates a weak relation of growth of money and real economic growth. Paper concludes that money and inflation both are man created phenomenon, so there is place for futher discussion to "cure" this illnesses.

Another significant study done by Katafono (2000) on the working papers of the National Bank of Fiji found out the simple correlation shows relationship of monetary aggregates with inflation and nominal GDP. Venezuelan economy needs to reconsider the monetary policy strategy because of; testing of the cointegration of M1 with CPI shows that they are related in the long run and the adjestment problems of fixed exchange rate system , suggests Olivo and Miller (2000) in the study done.

Literature considers that inflation and money have affected continuously each other and are man created phenomenon, generally from central banks of countries. An important point to put the light on is that countries with lower development and highly depended on policies of Unions, Example Balkan countries and their relation with EU, do not show a positive relation of $\mathrm{M} 1$ and $\mathrm{CPI}$, a hypothesis for this situation can be indirect effect of European Union policies on countries that are in the process of being part of it. Developing countries are trying to have their monetary policies in accordance with EU policies, in order to accelerate their integration. 


\section{Data and Methodology}

In order to examine the casual relation of prices and money supply in Albania, additionally to literature review and conceptual framework, econometric analysis is very important. The study employs monthly data from 2000:M1 to 2015:M1 used so for a 14 year period. Data for this research are obtained from Central Bank of Albania (BoA). All tests are performed using statistical program Eviews 8 . Prices are shown through CPI while money supply is presented as M1, which measures the most liquid components of money supply.

The regression model in this study is: $\underline{M 1}=\boldsymbol{a}+\beta_{1} C P I+e$

$\beta_{1}$; Intercept is the estimated regression coefficients

$\mathrm{e}$ : is the error term

M1: Money Supply, dependent variable

CPI: Customer Price Index, independent variable

The hypothesis for this equation is represented by the following:

$\mathrm{HO}$ : M1 is dependent on CPI

H1: $\mathrm{HO}$ is not true

Table 1: Estimates from Regression

\begin{tabular}{|c|c|c|c|c|}
\hline \multicolumn{5}{|c|}{$\begin{array}{l}\text { Dependent Variable: LOGM1_MIL_LEKS } \\
\text { Method: Least Squares } \\
\text { Date: 06/10/15 Time: } 14: 41 \\
\text { Sample: } 2000 \text { M01 2015M01 } \\
\text { Included observations: } 181\end{array}$} \\
\hline Variable & Coefficient & Std. Error & t-Statistic & Prob. \\
\hline LOGCPI & 1.722273 & 0.117857 & 14.61328 & 0.0000 \\
\hline$C$ & 2.611198 & 0.658735 & 3.963955 & 0.0001 \\
\hline R-squared & 0.544005 & \multicolumn{2}{|c|}{ Mean dependent var } & 12.23436 \\
\hline Adjusted R-squared & 0.541457 & \multicolumn{2}{|c|}{ S.D. dependent var } & 0.333167 \\
\hline S.E. of regression & 0.225607 & \multicolumn{2}{|c|}{ Akaike info criterion } & -0.129060 \\
\hline Sum squared resid & 9.110801 & \multicolumn{2}{|c|}{ Schwarz criterion } & -0.093717 \\
\hline Log likelihood & 13.67992 & \multicolumn{2}{|c|}{ Hannan-Quinn criter. } & -0.114731 \\
\hline F-statistic & 213.5479 & \multicolumn{2}{|c|}{ Durbin-Watson stat } & 0.513360 \\
\hline Prob(F-statistic) & 0.000000 & & & \\
\hline
\end{tabular}

In Figure 1 the graphical line plot represents the variables, money supply and prices in Albania. As it can be observed from the graph below they move in the same direction even though they have huge difference in the values (one of them high and the other small), the most visible fluctuation was in 2013 in CPI. While on Figure 2 the graphical scatter plot represents the relation of the variables, obviously they move in the same direction with very low fluctuations time to time.

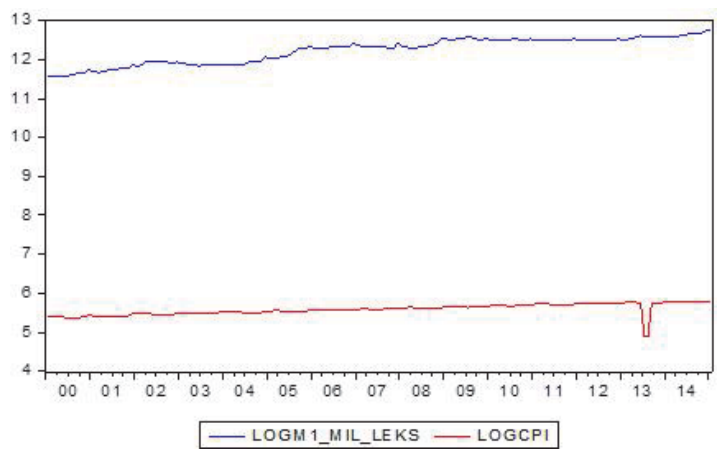

Figure 1: Line graph representing Money Supply (M1) and prices (CPI) 


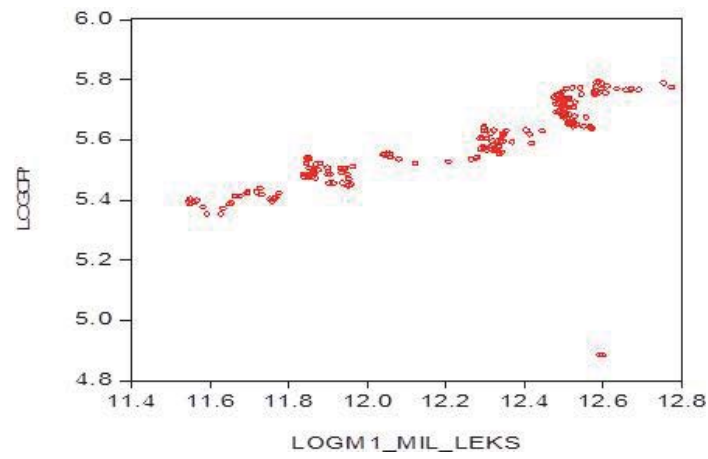

Figure 2: Scatter plot representing money supply and prices

\section{Empirical Findings}

Below in Table 2 and Figure 3 ( $A$ and B) are shown the group statistics performed with Eviews in order to test the normality of the data distribution. Check of Skweness and Kurtosis for the variables show that both variables are not perfectly bell shaped and asymmetric, even though money supply skewness is more near to 0 and kurtosis is near 1.5 that is sometimes considered to be acceptable, results lead to the conclusion that our variables have unit root presence. For the variables to have normality the skewness should be close to zero and kurtosis close to 3 as Hill at al. (2008) has emphasized.

Table 2: Group Statistics

\begin{tabular}{lcc}
\hline & LOGM1_MIL_LEKS & LOGCPI \\
\hline Mean & 12.23436 & 5.587479 \\
Median & 12.33207 & 5.594711 \\
Maximum & 12.77514 & 5.793014 \\
Minimum & 11.54625 & 4.882802 \\
Std. Dev. & 0.333167 & 0.142679 \\
Skewness & -0.516787 & -1.295632 \\
Kurtosis & 1.889618 & 7.644397 \\
Jarque-Bera & & \\
Probability & 17.35504 & 213.3166 \\
& 0.000170 & 0.000000 \\
Sum & & 1011.334 \\
Sum Sq. Dev. & 2214.420 & 3.664332 \\
Observations & 19.98003 & 181 \\
\hline
\end{tabular}
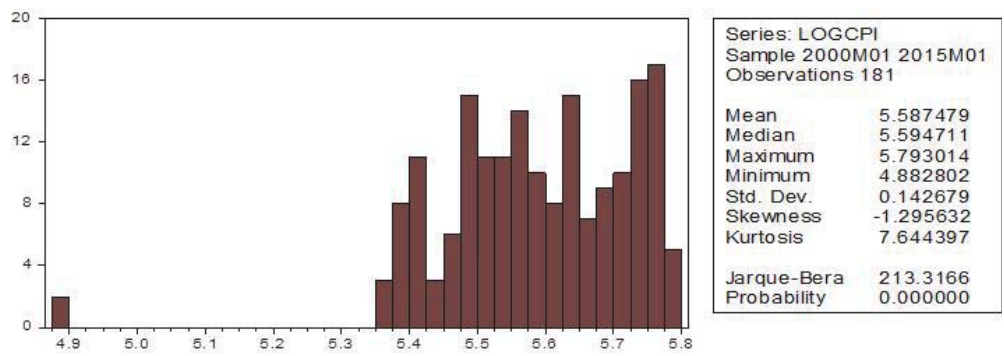

Figure 3A: Testing normality of distribution for CPI 


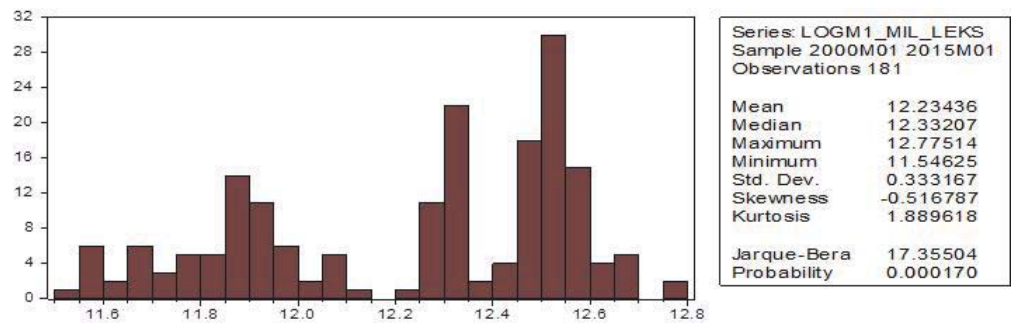

Figure 3B: Testing normality of distribution for M1

Time series data may be stationary or non stationary, in order not to have the danger of not having significant regression results, in the first stage of the study Augmented Dickey-Fuller (ADF) test at 5\% level of significance is conducted in order to estimate that series used in the model are stationary in times series. First we could observe that both variables have unit root and are rejected at 5\% significance level, as p-value is higher than the percentage of significance. So unit roots in the series should be avoided by converting variables in non stationary. To overcome this, Dickey-Fuller unit root test is performed again, second difference of ADF unit root test transformed variables to non stationary

Table 3: ADF tests for M1

ADF Unit Root for M1

Null Hypothesis: LOGM1_MIL_LEKS has a unit root

Exogenous: Constant

Lag Length: 13 (Automatic - based on SIC, maxlag=16)

\begin{tabular}{lcrc}
\hline & \multicolumn{2}{c}{ t-Statistic } & Prob. $^{*}$ \\
Augmented Dickey-Fuller test statistic & 1\% level & -1.201457 & 0.6735 \\
\hline Test critical values: & $5 \%$ level & -2.878723 & \\
& $10 \%$ level & -2.576010 & \\
\hline
\end{tabular}

Mackinnon (1996) one-sided p-values.

Table 4: ADF test for M1, Second difference

\begin{tabular}{|c|c|c|c|}
\hline \multicolumn{4}{|c|}{$\begin{array}{l}\text { Null Hypothesis: D(LOGM1_MIL_LEKS,2) has a unit root } \\
\text { Exogenous: Constant } \\
\text { Lag Length: } 11 \text { (Automatic - based on SIC, maxlag=16) }\end{array}$} \\
\hline & & t-Statistic & Prob.* \\
\hline \multicolumn{2}{|l|}{ Augmented Dickey-Fuller test statistic } & -5.900543 & 0.0000 \\
\hline \multirow[t]{3}{*}{ Test critical values: } & $1 \%$ level & -3.469691 & \\
\hline & $5 \%$ level & -2.878723 & \\
\hline & $10 \%$ level & -2.576010 & \\
\hline
\end{tabular}

Mackinnon (1996) one-sided p-values.

Table 5: ADF test for M1, Second difference and Linear Trend

\begin{tabular}{lrrr}
\hline $\begin{array}{l}\text { Null Hypothesis: D(LOGM1_MIL_LEKS,2) has a unit root } \\
\text { Exogenous: Constant }\end{array}$ & & \\
Lag Length: 11 (Automatic - based on SIC, maxlag=16) & & \\
\hline & & t-Statistic & Prob. $^{*}$ \\
\hline Augmented Dickey-Fuller test statistic & -5.900543 & 0.0000 \\
\hline Test critical values: & 1\% level & -3.469691 & \\
& $5 \%$ level & -2.878723 & \\
\hline
\end{tabular}

*MacKinnon (1996) one-sided p-values. 
Table 6: ADF test for CPI

ADF Unit Root for CPI

\begin{tabular}{llll}
\hline $\begin{array}{l}\text { Null Hypothesis: LOGCPI has a unit root } \\
\text { Exogenous: Constant }\end{array}$ & & \\
Lag Length: 4 (Automatic - based on SIC, maxlag=16) & & \\
\hline & & t-Statistic & Prob. $^{*}$ \\
\hline & & -2.292155 & 0.1757 \\
\hline Augmented Dickey-Fuller test statistic & $1 \%$ level & -3.467633 & \\
\hline & $5 \%$ level & -2.877823 & \\
\hline
\end{tabular}

*MacKinnon (1996) one-sided p-values.

Table 7: ADF test for CPI, Second difference

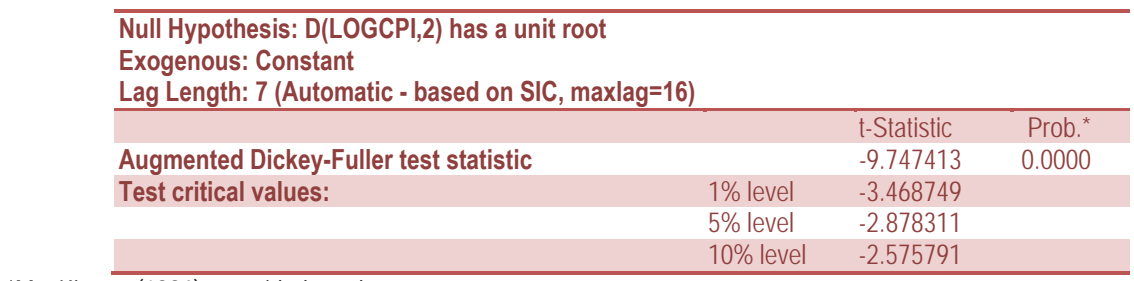

*MacKinnon (1996) one-sided p-values.

Table 8: ADF test for CPI, Second difference and Linear Trend

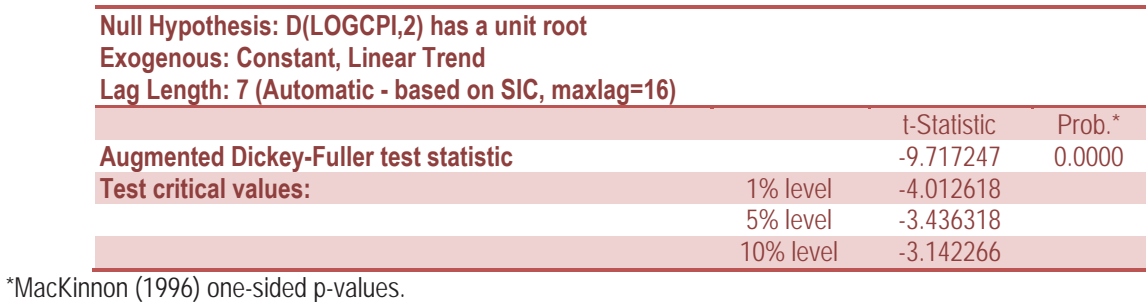

Before analyzing the co integration relationship between money supply and prices, univariate analysis should be done. As economic series like M1 and CPI have unit roots. Both dependent and independent variables having unit root means the regression is spurious. The relation of variables shows to be significant but in reality it is contemporary relation and not casual.

Based on the above unit root tests performance another important test to be done is; Johansen Co integration test in order to check for any co integration of variables in the long run.

Table 9: Unrestricted Co integration test (Trace and Maximum Eigenvalue)

Unrestricted Co integration Rank Test (Trace)

\begin{tabular}{lcccc}
\hline Hypothesized No. of CE(s) & Eigenvalue & Trace Statistic & 0.05 Critical Value & Prob. ${ }^{* *}$ \\
\hline None $^{*}$ & 0.143771 & 29.39376 & 15.49471 & 0.0002 \\
At most 1 & 0.011723 & 2.075408 & 3.841466 & 0.1497 \\
\hline
\end{tabular}

Trace test indicates 1 cointegrating eqn(s) at the 0.05 level

* denotes rejection of the hypothesis at the 0.05 level

**MacKinnon-Haug-Michelis (1999) p-values 
Unrestricted Co integration Rank Test (Maximum Eigenvalue)

\begin{tabular}{ccccc}
\hline Hypothesized No. of CE(s) & Eigenvalue & Max-Eigen Statistic & $\mathbf{0 . 0 5}$ Critical Value & Prob. $^{* *}$ \\
\hline None $^{*}$ & 0.143771 & 27.31835 & 14.26460 & 0.0003 \\
At most 1 & 0.011723 & 2.075408 & 3.841466 & 0.1497 \\
\hline
\end{tabular}

Max-eigenvalue test indicates 1 cointegrating eqn(s) at the 0.05 level

* denotes rejection of the hypothesis at the 0.05 level

**MacKinnon-Haug-Michelis (1999) p-values

The results of $\mathrm{JC}$ Trace Test (first part of the test) there is $1 \mathrm{co}$ integrating equation at the 0.05 level. As Trace statistics is greater than critical value $(29.39>15.59)$. The results of JC Max Eugenvalue Test (second part of the test) there is $1 \mathrm{co}$ integrating equation at the 0.05 level. As Max-Eigen statistics is greater than critical value $(27.31>14.26)$.

From the Johansen Co integration test it can be observed that both Trace Rank Test and Maximum Eigenvalue have the probabilities smaller than $\mathrm{p}$-value, indicating that as both probabilities are smaller than significance level of $5 \%$ the relation of variables is strong. . Long run relationship of money supply and prices exists.

Additionally to co integrated equation of $\mathrm{M} 1$ and $\mathrm{CPI}$ in the long run that was estimated with Johansen Co integration test, in order to find out the short term dynamics of the model Error Correction Model (ECM) must be used. Engel and Granger (1987) suggest ECM for causality.

ECM finds out the long run relation and short term adjustment behavior or co integration of disequilibrium. The variables that are related and move together in short term and have shocks or the disequilibrium, in the long run these are being eliminated and they are being equalized again. This indicates that long run situation is statistically significant. (Turan, 2015)

To perform Vector Error Correction Model (VECM) test in Eviews 8 first of all the variables must be stationary and co integrated. In the estimation of the equation trend must be added as the variables have trend. In the regression model residuals are added also, checking them to be stationary and a new regression model is set with first difference, showing that in the new model P value of residuals is lower than 0.05 . From the results is can be concluded that model is valid and significant. (See Table 10).

Table 10: The results of the regression

\begin{tabular}{|c|c|c|}
\hline \multicolumn{3}{|c|}{ Dependent Variable: D(LOGM1_MIL_LEKS) } \\
\hline \multicolumn{3}{|c|}{ Method: Least Squares } \\
\hline \multirow{2}{*}{\multicolumn{3}{|c|}{ Date: 06/10/15 Time: $15: 38$}} \\
\hline \multirow{2}{*}{\multicolumn{3}{|c|}{$\begin{array}{l}\text { Sample (adjusted): 2000M02 2015M01 } \\
\text { Included observations: } 180 \text { after adjustments }\end{array}$}} \\
\hline & & \\
\hline Determinant & Coefficient & Probability \\
\hline $\mathrm{D}(\mathrm{LOGCPI})$ & 0.009332 & 0.6844 \\
\hline RESID01(-1) & -0.042911 & 0.0373 \\
\hline C -2 & 0.006680 & 0.0019 \\
\hline
\end{tabular}

Note: the lag was selected according to selection criteria (the result with the most starts) in the VAR Lag Order Selection Criteria. LAG 4 was selected.

As the co integration vector of the variables exists, in this case the last step is determining the direction of the relation. Granger causality test is used to determine the direction and is presented in Table 10. In order to perform Granger causality test the variables should be stationary and VAR model should be formulated.

Table 11: Granger Causality test results

\section{VAR Granger Causality/Block Exogeneity Wald Tests}

Date: 06/10/15 Time: 15:41

Sample: 2000M01 2015M01 
Included observations: 177

\begin{tabular}{cccc}
\hline \multicolumn{5}{c}{ Dependent variable: LOGM1_MIL_LEKS } \\
\hline Excluded & Chi-sq & df & Prob. \\
\hline LOGCPI & 1.698764 & 4 & 0.7909 \\
All & 1.698764 & 4 & 0.7909 \\
\hline & Dependent variable: LOGCPI & \\
\hline Excluded & Chi-sq & df & Prob. \\
\hline LOGM1_MIL_LEKS & 32.95409 & 4 & 0.0000 \\
All & 32.95409 & 4 & 0.0000 \\
\hline
\end{tabular}

From the results of the Granger Causality test it can be observed that probabilities that increase in the prices does not cause money supply to be increased but on the other side increase in money supply effects the prices in the market in Albanian economy.

Table 12: Pair-wise Granger causality test

\begin{tabular}{lccc}
\hline Direction of causality & Lag & Probability & Decision \\
\hline CPI does not Granger cause M1 & 4 & 0.7909 & Accepted \\
M1 does not Granger cause CPI & 4 & 0.0000 & Rejected \\
\hline
\end{tabular}

\section{Conclusion}

This research emphasized the casual relationship of money supply and prices in Albania, using Johansen Co integration test to test the co integration and Granger causality test to test the direction of the relation. The empirical results show that a stable long run relationship exists between the variables. The Granger test shows that money supply increases cause the prices in the market to increase and the CPI index is affected from the changes in M1.

\section{References}

BoA, B. o. (n.d.). Bank of Albania. Retrieved March 2015, from http://www.bankofalbania.org/web/About_Inflation_5266_2.php Gaurisankar, S., Jahngir-Abdoelrahman, S., Eckhorst, K., Amatali-Sisal, W., Warsosemito, R., \& Wondel, D. (2011). Short-Run and Long-Run Relationship between money and prices: The case of Suriname. 43rd Annual Monetary Studies Conference/ November. Bridgetown.

INSTAT. (2015). Monthly Report, March . Tirane : INSTAT

Katafono, R. (2000). The relationship between monetary aggregates, inflation and output in Fiji. Working Paper of Reserve Bank of Fiji/ Economics Department .

Madurapperuma, A. (2007). Money, inflation and growth; Review of the concepts and past relationships. 19th Anniversary Concention 2007 (pp. 59-92). Sri Lanka: Association of Professional Bankers

Muco, M., Sanfey, P., \& Taci, A. (2004). Inflation, exchange rates and the role of monetary policy in Albania. Working Paper No.88/ European Bank for Reconstruction and Development .

Olivo, V., \& Miller, S. M. (2000). The Long-Run Relationship between Money, Nominal GDP, and the Price Level in Venezuela: 19501996. Deparment of Economics Working Paper Series/ University of Connecticut .

Paun, C., \& Topan, V. (2013). The monetary causes of inflation in Romania. Romanian Journal of Economic Forcasting , 5-23.

Simic, V., \& Malesevic-Perovic, L. (July, 2012). Monetary Policy Transmission in the Ballkans in the 21st Centrury: Emirical Evidence . Journal of Economic and Social Studies .

Turan, G. (2015). Non-Stationary Times Series Regression: How to perform an application by using E-VIEWS 7. Tirane: Working Paper, Epoka University, Economics Department. 